\title{
COMPARATIVE STUDY BETWEEN THE EFFECTIVENESS OF N- ACETYLCYSTEINE AND BICARBONATE IN RENAL PROTECTION AFTER CARDIAC BYPASS SURGERY
}

\author{
Galal A. El Kady, Sherif G. Anis, Amr A. Kasem, Mostafa M. Serry and \\ Alia M. Mohamed
}

Department of Anesthesia \& Intensive Care and Pain Management, Faculty of Medicine - Ain Shams University, Cairo, Egypt Corresponding :

Alia M. Mohamed

Mobile: 01282003853

E mail:

aliamohamed1987@hotmail.com

Received: $18 / 7 / 2019$

Accepted: 21/8/2019

\begin{abstract}
:
Background: Cardiac surgery-associated acute kidney injury is a common and serious postoperative complication of cardiac surgery that employs cardiopulmonary bypass. Acute renal failure occurs in up to $30 \%$ of patients who undergo cardiac surgery.
\end{abstract}

Aim of the Work: to compare between the effectiveness of acetylcysteine and bicarbonate in prevention of acute kidney injury in patients undergoing elective cardiac bypass surgeries.

Patients and Methods: This interventional prospective comparative randomized single blinded study was conducted on 120 cardiac patients, hypertensive, diabetic with normal preoperative kidney functions, of either sex, aging $>40$ years old, scheduled for elective cardiac bypass surgery at Cardiothoracic Surgery Department of Ain Shams University hospitals. Study started June 2017 and ended December 2018; after the approval of the ethical medical committee and obtaining a written informed consent from the patient.

Results: The current study showed nonsignificant correlation between usage of NAC and bicarbonate and renal protection after cardiac bypass surgeries. Also the current study showed the more the time of aortic clamping, time of CPB and the lower the MAP during $C P B$, the more the rise in serum creatinine after 24 hours.

Conclusion: The current study shows that perioperative intravenous administration of NAC with or without sodium bicarbonate may not have a role in prevention of acute kidney injury in patients undergoing elective cardiac bypass surgeries as detected by serum creatinine and creatinine clearance.

Key words: N-acetylcysteine, Bicarbonate, Renal Protection, Cardiac Bypass Surgery

\section{INTRODUCTION:}

Cardiac surgery-associated acute kidney injury (CSA-AKI) is a common and serious postoperative complication of cardiac surgery that requires cardiopulmonary bypass $(\mathrm{CPB})^{(\mathbf{1})}$.

Due to the difference in surgery type, the range of incidence is between 8.9 and $39 \%$. Isolated CABG has the lowest incidence of $\mathrm{AKI}$, followed by valvular surgery and combined CABG with valvular surgery in series ${ }^{(2,3)}$.

Risk factors associated with the development of CSA-AKI have been well established. Preoperative risk factors include advanced age, female gender, reduced left ventricular function or congestive heart failure, diabetes mellitus, peripheral vascular disease, emergent surgery, and preoperative elevated serum creatinine ${ }^{(4)}$. 
CSA-AKI is caused by a variety of factors including metabolic abnormalities, ischemia and reperfusion injury, neurohormonal activation, inflammation, and oxidative stress $^{(5)}$.

Also during the perioperative period, the volume status of the patients is of importance. Other factor of major importance is low cardiac output, before, during, or after surgery, that is directly related to AKI risk ${ }^{(6)}$.

Additional factors include aortic crossclamping and declamping techniques, blood transfusion, hypothermia and hemolysis ${ }^{(2)}$.

Identification of patients before surgery who are at high risk for developing CSAAKI should permit the efficient application of prophylactic and therapeutic measures ${ }^{(7)}$.

Sodium bicarbonate causes urinary alkalinization that may protect renal tissues from injury induced by oxidant substances, complement activation, and hemoglobininduced pigment nephropathy ${ }^{(8)}$.

$\mathrm{N}$-acetylcysteine (NAC) reduces proinflammatory cytokines, oxygen free-radical production, and ameliorates ischemia reperfusion injury; therefore, it may theoretically reduce postoperative complications in cardiac surgery ${ }^{(\mathbf{9})}$.

\section{AIM OF THE WORK:}

The aim of this study is to compare between the effectiveness of acetyl cysteine and bicarbonate in prevention of acute kidney injury in patients undergoing elective cardiac bypass surgeries.

\section{PATIENTS AND METHODS:}

One hundred and twenty cardiac patients, hypertensive, diabetic with normal preoperative kidney functions, of either sex, aging $>40$ years old, were scheduled for elective cardiac bypass surgery at
Cardiothoracic Surgery Department of Ain Shams University hospitals. Study started June 2017 and ended December 2018. It was an interventional prospective comparative randomized single blinded study after the approval of the ethical medical committee and obtaining a written informed consent from the patient.

\section{Exclusion criteria:}

Patients with the following criteria were excluded from the study, emergency operation, patients who had allergy to NAC, or prior adverse reaction to NAC (e.g generalized rash, urticarial, bronchospasm, hypotension), patients scheduled for off pump surgery or extracardiac procedure e.g. pericardictomy, patients who required chronic dialysis, patient unable to give informed consent (e.g dementia), patients with preoperative serum creatinine more than $1.5 \mathrm{mg} / \mathrm{dl}$.

\section{Preoperative evaluation:}

All patients were subjected to the following: clinical examination, ECG, Routine laboratory investigations including complete blood count (CBC), random blood sugar (RBS), liver function test (LFT), kidney function test (KFT), prothrombin time (PT) and partial thromboplastin time (PTT), Echocardiography examination with full study and measurement of cardiac volume, and function.

\section{Anesthetic technique:}

All patients were premedicated with oral diazepam $(5 \mathrm{mg})$ at the morning of the operation. A peripheral intravenous cannula was inserted. The left radial artery was cannulated.

Anesthesia was induced with propofol $(2 \mathrm{mg} / \mathrm{kg})$, cisatracurium $(0.15 \mathrm{mg} / \mathrm{kg})$, and fentanyl (5microgram $/ \mathrm{kg})$, intravenously. Anesthesia was maintained with isoflurane, increments of fentanyl, morphine and incremental doses of cisatracurium $(0.03 \mathrm{mg} / \mathrm{kg})$ as needed. Central venous line 
was inserted under complete aseptic conditions.

Mechanical ventilation was maintained until the start of the CPB.

Immediately after the induction of anesthesia, before the first surgical incision, group A received NAC at an intravenous dose of $150 \mathrm{mg} / \mathrm{kg}$ in $250 \mathrm{ml}$ of $5 \%$ glucose over $15 \mathrm{~min}$, followed by a continuous intravenous infusion of $50 \mathrm{mg} / \mathrm{kg}$ in $250 \mathrm{ml}$ of $5 \%$ glucose over $4 \mathrm{~h}$ and then $100 \mathrm{mg} / \mathrm{kg}$ in $250 \mathrm{ml}$ of $5 \%$ glucose over $20 \mathrm{~h}$ (total dose $=300 \mathrm{mg} / \mathrm{kg}$ body weight over $24 \mathrm{~h}$ ). Group B received sodium bicarbonate $8.4 \%$ ( $90 \mathrm{ml}$ of bicarbonate added on glucose $5 \%$ infused at rate of $3 \mathrm{ml} / \mathrm{kg} /$ hour immediately after induction of anesthesia, prior to the first surgical incision, followed by 1 $\mathrm{mL} / \mathrm{kg}$ /hour for 24 hours. Group C received combination of bicarbonate and NAC in equivalent previos doses and volumes over the same period. Group D received $750 \mathrm{ml}$ of glucose $5 \%$ over the same period.

Cardiopulmonary bypass technique after heparin administration at a dose of 3$5 \mathrm{mg} / \mathrm{kg}$, aortic and right heart cannulation was performed. CPB was established once the activated clotting time was greater than $450 \mathrm{~s}, \mathrm{CPB}$ was instituted with a non pulsatile heart-lung machine, with the blood flow maintained at $2-2.41 / \mathrm{min} / \mathrm{m} 2$. The prime volume comprised of mannitol, crystalloid solutions and heparin. The target was to keep hematocrit at about $24 \%$ after initiation of CPB. The body temperature during bypass was maintained between 28 and 30C. After removal of the ACC, and the reperfusion at normothermic $\mathrm{CPB}$, weaning off bypass was done, where Adrenaline (40$400 \mathrm{ng} / \mathrm{kg} / \mathrm{min}$.) was the first choice if inotropes were needed, while Nitroglycerine $(0.5-10 \quad$ microgram $/ \mathrm{kg} / \mathrm{min}$.) was the first choice if vasodilators were needed.

\section{Measurements:}

\section{Preoperative measurements:}

HR, MAP, temperature, CVP, hemoglobin level, $\mathrm{EF} \%$, serum urea, serum electrolytes, $\mathrm{PH}$ and $\mathrm{HCO} 3$ of arterial blood gas sampling, serum creatinine and creatinine clearance were recorded.

\section{Intraoperative measurements:}

RBS, CVP and UOP were recorded every hour all through operation.

Invasive mean arterial blood pressure were continuously monitored and recorded for the sake of the study at the following intervals (5min after induction, before going on bypass, the lowest reading during bypass).

Time of operation and time of aortic clamping were documented.

\section{Postoperative measurements:}

Serum urea, serum creatinine, creatinine clearance, electrolytes $(\mathrm{Na}, \mathrm{K}), \mathrm{PH}$ and $\mathrm{HCO} 3$ of arterial blood gas sampling, UOP, RBS and vital data were recorded at the following intervals; immediately postoperative and every 6 hours for 24 hours starting from end of operation.

\section{Statistical analysis:}

Recorded data were analyzed using the statistical package for social sciences, version 20.0 (SPSS Inc., Chicago, Illinois, USA). Quantitative data were expressed as mean \pm standard deviation (SD). Qualitative data were expressed as frequency and percentage.

- Probability (P-value)

- P-value $<0.05$ was considered significant.

- P-value $<0.001$ was considered as highly significant.

- P-value $>0.05$ was considered insignificant. 


\section{RESULTS:}

One hundred and twenty patients were subjected to the current study,15 patients were excluded from that study. five patients died, six patients developed postoperative bleeding and reopened and four patients developed allergy from acetylcysteine.

Table (1): Comparison between groups according to serum creatinine ( $\mathrm{mg} / \mathrm{dl})$

\begin{tabular}{|l|c|c|c|c|c|c|}
\hline \multicolumn{1}{|c|}{ Serum creatinine } & $\begin{array}{c}\text { Group A } \\
(n=28)\end{array}$ & $\begin{array}{c}\text { Group B } \\
(n=26)\end{array}$ & $\begin{array}{c}\text { Group C } \\
(n=26)\end{array}$ & $\begin{array}{c}\text { Group D } \\
(n=25)\end{array}$ & ANOVA & p-value \\
\hline Baseline & $0.79 \pm 0.12$ & $0.79 \pm 0.14$ & $0.78 \pm 0.20$ & $0.77 \pm 0.18$ & 1.492 & 0.540 \\
\hline Immediately postoperative & $0.74 \pm 0.11$ & $0.77 \pm 0.14$ & $0.77 \pm 0.20$ & $0.78 \pm 0.18$ & 1.865 & 0.092 \\
\hline 6 hrs. postoperative & $0.68 \pm 0.10$ & $0.74 \pm 0.14$ & $0.75 \pm 0.20$ & $0.69 \pm 0.18$ & 1.574 & 0.274 \\
\hline 12 hrs. postoperative & $0.86 \pm 0.15$ & $0.85 \pm 0.20$ & $0.81 \pm 0.20$ & $0.88 \pm 0.19$ & 0.989 & 0.608 \\
\hline 18 hrs. postoperative & $0.94 \pm 0.13$ & $0.91 \pm 0.23$ & $0.94 \pm 0.39$ & $1.04 \pm 0.19$ & 1.460 & 0.229 \\
\hline 24 hrs. postoperative & $1.03 \pm 0.20$ & $0.98 \pm 0.28$ & $1.04 \pm 0.55$ & $1.15 \pm 0.31$ & 1.181 & 0.320 \\
\hline
\end{tabular}

F- One Way ANOVA; p-value >0.05 NS;

This table shows no statistically significant difference between groups according to serum creatinine $(\mathrm{mg} / \mathrm{dl})$.

Table (2): Comparison between groups according to serum sodium ( $\mathrm{mmol} / \mathrm{l})$

\begin{tabular}{|c|c|c|c|c|c|c|}
\hline Serum sodium & $\begin{array}{c}\text { Group A } \\
(n=28)\end{array}$ & $\begin{array}{c}\text { Group B } \\
(n=26)\end{array}$ & $\begin{array}{c}\text { Group C } \\
(n=26)\end{array}$ & $\begin{array}{c}\text { Group D } \\
(n=25)\end{array}$ & ANOVA & p-value \\
\hline Baseline & $138.20 \pm 1.63$ & $137.30 \pm 1.82$ & $137.90 \pm 1.60$ & $137.60 \pm 1.83$ & 1.513 & 0.215 \\
\hline $\begin{array}{l}\text { Immediately } \\
\text { postoperative }\end{array}$ & $138.20 \pm 1.63$ & $139.90 \pm 1.95$ & $138.70 \pm 1.58$ & $137.80 \pm 1.75$ & 1.922 & 0.118 \\
\hline 6 hrs. postoperative & $138.90 \pm 1.84$ & $145.30 \pm 1.70^{\dagger}$ & $146.20 \pm 1.49^{\dagger}$ & $138.60 \pm 1.83^{\ddagger \#}$ & 16.267 & $<0.001 * *$ \\
\hline 12 hrs. postoperative & $139.20 \pm 1.63$ & $146.60 \pm 2.81^{\dagger}$ & $148.10 \pm 1.24^{\dagger}$ & 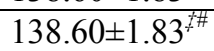 & 18.303 & $<0.001 * *$ \\
\hline 18 hrs. postoperative & $139.90 \pm 1.84$ & $148.70 \pm 2.81^{\dagger}$ & $150 \pm 1.20^{\dagger}$ & $139.10 \pm 1.84^{\text {\#\# }}$ & 23.527 & $<0.001 * *$ \\
\hline 24 hrs. postoperative & $140.20 \pm 1.63$ & $150.60 \pm 2.85^{\dagger}$ & $152.20 \pm 1.63^{\dagger}$ & $139.60 \pm 1.83^{\text {劷 }}$ & 19.143 & $<0.001 * *$ \\
\hline
\end{tabular}

F- One Way ANOVA; p-value $>0.05 \mathrm{NS} ;{ }^{* *}$-value $<0.001 \mathrm{HS}$

Post Hoc:

†: Significant difference with group A ( $p$-value $<0.05 S$ )

¥: Significant difference with group $B(p$-value $<0.05 S)$

\#: Significant difference with group $C(p$-value $<0.05 S)$

This table shows statistically significant difference between groups according to and 24 hours after end of surgery. Values are serum sodium samples obtained at $6,12,18$ higher in group B and C.

Table (3): Comparison between groups according to serum potassium ( $\mathrm{mmol} / \mathrm{l})$

\begin{tabular}{|l|c|c|c|c|c|c|}
\hline \multicolumn{1}{|c|}{ Serum potassium } & $\begin{array}{c}\text { Group A } \\
(n=28)\end{array}$ & $\begin{array}{c}\text { Group B } \\
(n=26)\end{array}$ & $\begin{array}{c}\text { Group C } \\
(n=26)\end{array}$ & $\begin{array}{c}\text { Group D } \\
(n=25)\end{array}$ & ANOVA & p-value \\
\hline Baseline & $3.82 \pm 0.19$ & $3.79 \pm 0.16$ & $3.81 \pm 0.20$ & $3.77 \pm 0.16$ & 0.469 & 0.704 \\
\hline Immediately postoperative & $4.06 \pm 0.24$ & $3.91 \pm 0.37$ & $4.03 \pm 0.37$ & $4.11 \pm 0.31$ & 1.023 & 0.115 \\
\hline 6 hrs. postoperative & $4.37 \pm 0.18$ & $4.09 \pm 0.33$ & $4.13 \pm 0.37$ & $4.26 \pm 0.26$ & 0.516 & 0.774 \\
\hline 12 hrs. postoperative & $4.40 \pm 0.22$ & $4.07 \pm 0.29$ & $4.18 \pm 0.48$ & $4.29 \pm 0.34$ & 1.125 & 0.127 \\
\hline 18 hrs. postoperative & $4.44 \pm 0.16$ & $4.14 \pm 0.24$ & $4.25 \pm 0.45$ & $4.36 \pm 0.26$ & 0.567 & 0.852 \\
\hline 24 hrs. postoperative & $4.38 \pm 0.11$ & $4.21 \pm 0.19$ & $4.29 \pm 0.32$ & $4.42 \pm 0.17$ & 1.238 & 0.139 \\
\hline
\end{tabular}

F- One Way ANOVA; p-value >0.05 NS;

This table shows no statistically significant difference between groups according to serum potassium (mmol/1). 
Comparative study between the effectiveness of $n$-acetylcysteine and bicarbonate in renal protection...

Table (4): Comparison between groups according to creatinine clearance ( $\mathrm{ml} / \mathrm{min}$.)

\begin{tabular}{|l|c|c|c|c|c|c|}
\hline \multicolumn{1}{|c|}{ Creatinine clearance } & $\begin{array}{c}\text { Group A } \\
(n=28)\end{array}$ & $\begin{array}{c}\text { Group B } \\
(n=26)\end{array}$ & $\begin{array}{c}\text { Group C } \\
(n=26)\end{array}$ & $\begin{array}{c}\text { Group D } \\
(n=25)\end{array}$ & ANOVA & p-value \\
\hline Baseline & $116.21 \pm 16.45$ & $118.26 \pm 12.23$ & $118.17 \pm 19.27$ & $115.43 \pm 22.03$ & 1.125 & 0.127 \\
\hline Immediately postoperative & $118.84 \pm 18.89$ & $121.93 \pm 13.09$ & $117.01 \pm 19.30$ & $116.24 \pm 22.53$ & 0.567 & 0.852 \\
\hline 6 hrs. postoperative & $116.54 \pm 22.59$ & $115.73 \pm 14.19$ & $118.80 \pm 20.96$ & $119.11 \pm 23.44$ & 1.238 & 0.139 \\
\hline 12 hrs. postoperative & $111.16 \pm 16.59$ & $112.76 \pm 15.88$ & $113.21 \pm 17.82$ & $109.77 \pm 21.31$ & 0.624 & 0.613 \\
\hline 18 hrs. postoperative & $96.55 \pm 36.01$ & $96.36 \pm 16.38$ & $103.39 \pm 23.36$ & $106.35 \pm 20.43$ & 1.188 & 0.317 \\
\hline 24 hrs. postoperative & $98.65 \pm 19.67$ & $90.74 \pm 19.03$ & $97.86 \pm 25.85$ & $98.73 \pm 23.62$ & 0.903 & 0.442 \\
\hline
\end{tabular}

F- One Way ANOVA; p-value >0.05 NS;

This table shows no statistically significant difference between groups according to creatinine clearance $(\mathrm{ml} / \mathrm{min}$.).

Table (5): Comparison between groups according to $(\mathrm{pH})$ of arterial blood gas samling

\begin{tabular}{|l|c|c|c|c|c|c|}
\hline \multicolumn{1}{|c|}{ Arterial blood gas $(\mathrm{pH})$} & $\begin{array}{c}\text { Group A } \\
(n=28)\end{array}$ & $\begin{array}{c}\text { Group B } \\
(n=26)\end{array}$ & $\begin{array}{c}\text { Group C } \\
(n=26)\end{array}$ & $\begin{array}{c}\text { Group D } \\
(n=25)\end{array}$ & ANOVA & p-value \\
\hline Baseline & $7.39 \pm 0.03$ & $7.37 \pm 0.03$ & $7.37 \pm 0.02$ & $7.38 \pm 0.02$ & 1.063 & 0.310 \\
\hline Immediately postoperative & $7.36 \pm 0.05$ & $7.38 \pm 0.02$ & $7.37 \pm 0.03$ & $7.36 \pm 0.02$ & 1.369 & 0.247 \\
\hline 6 hrs. postoperative & $7.34 \pm 0.03$ & $7.44 \pm 0.02^{\dagger}$ & $7.40 \pm 0.05^{\dagger}$ & $7.34 \pm 0.02^{\text {ॠ\# }}$ & 7.866 & $<0.001^{* *}$ \\
\hline 12 hrs. postoperative & $7.33 \pm 0.02$ & $7.44 \pm 0.03^{\dagger}$ & $7.41 \pm 0.06^{\dagger}$ & $7.35 \pm 0.02^{\text {ॠ\# }}$ & 7.971 & $<0.001^{* *}$ \\
\hline 18 hrs. postoperative & $7.34 \pm 0.02$ & $7.45 \pm 0.04^{\dagger}$ & $7.42 \pm 0.05^{\dagger}$ & $7.34 \pm 0.02^{\text {ॠ\# }}$ & 6.393 & $<0.001^{* *}$ \\
\hline 24 hrs. postoperative & $7.35 \pm 0.02$ & $7.47 \pm 0.04^{\dagger}$ & $7.44 \pm 0.05^{\dagger}$ & $7.35 \pm 0.02^{\text {ॠ\# }}$ & 8.564 & $<0.001^{* *}$ \\
\hline
\end{tabular}

F- One Way ANOVA; p-value $>0.05$ NS; **p-value $<0.001 \mathrm{HS}$

Post Hoc:

†: Significant difference with group A ( $p$-value $<0.05 S)$

$¥$ : Significant difference with group B (p-value $<0.05 S)$

\#: Significant difference with group C ( $p$-value $<0.05 \mathrm{~S})$

This table shows statistically significant difference between groups according to $(\mathrm{pH})$

12,18 and 24 hours postoperative starting from end of operation. Values are higher in of arterial blood gas samples obtained at 6 , group $\mathrm{B}$ and $\mathrm{C}$.

Table (6): Comparison between groups according to $\left(\mathrm{HCO}_{3}\right)$ of arterial blood gas sampling $(\mathrm{mmol} / \mathrm{l})$

\begin{tabular}{|c|c|c|c|c|c|c|}
\hline Arterial blood gas (HCO3) & $\begin{array}{c}\text { Group A } \\
(n=28)\end{array}$ & $\begin{array}{c}\text { Group B } \\
(n=26)\end{array}$ & $\begin{array}{c}\text { Group C } \\
(n=26)\end{array}$ & $\begin{array}{c}\text { Group D } \\
(n=25)\end{array}$ & ANOVA & p-value \\
\hline Baseline & $23.65 \pm 1.06$ & $23.41 \pm 0.92$ & $23.50 \pm 1.16$ & $23.47 \pm 1.19$ & 0.264 & 0.851 \\
\hline Immediately postoperative & $23.17 \pm 1.73$ & $24.01 \pm 0.92$ & $23.10 \pm 2.12$ & $22.97 \pm 1.19$ & 1.894 & 0.211 \\
\hline 6 hrs. postoperative & $21.93 \pm 1.18$ & $24.91 \pm 0.92^{\dagger}$ & $26.25 \pm 2.51^{\dagger}$ & $22.16 \pm 1.32^{\ddagger \#}$ & 52.133 & $<0.001 * *$ \\
\hline 12 hrs. postoperative & $22.53 \pm 1.07$ & $26.20 \pm 1.02^{\dagger}$ & $27.40 \pm 2.80^{\dagger}$ & $22.66 \pm 1.32^{\text {f\# }}$ & 62.596 & $<0.001 * *$ \\
\hline $18 \mathrm{hrs}$. postoperative & $23.08 \pm 1$ & $27.65 \pm 0.97^{\dagger}$ & $27.80 \pm 1.12^{\dagger}$ & $23.16 \pm 1.32^{\text {F\# }}$ & 172.579 & $<0.001 * *$ \\
\hline 24 hrs. postoperative & $23.43 \pm 0.96$ & $29.78 \pm 1.04^{\dagger}$ & $29.85 \pm 1.25^{\dagger}$ & $23.46 \pm 1.32^{\ddagger \#}$ & 307.507 & $<0.001^{* *}$ \\
\hline
\end{tabular}

F- One Way ANOVA; p-value >0.05 NS; **p-value $<0.001 \mathrm{HS}$

Post Hoc:

t: Significant difference with group A (p-value $<0.05 \mathrm{~S})$

¥: Significant difference with group $B(p$-value $<0.05 S)$

\#: Significant difference with group $C(p$-value $<0.05 S)$

This table shows statistically significant obtained at $6,12,18$ and 24 hours difference between groups according to postoperative starting from end of operation.

$\mathrm{HCO}_{3}(\mathrm{mmol} / \mathrm{l})$ of arterial blood gas samples 
Galal A. El Kady, et al.,

Table (7): Comparison between groups according to outcome evaluation of patients postoperatively

\begin{tabular}{|c|c|c|c|c|c|c|}
\hline Outcome & $\begin{array}{c}\text { Group A } \\
(n=30)\end{array}$ & $\begin{array}{c}\text { Group B } \\
(n=30)\end{array}$ & $\begin{array}{c}\text { Group C } \\
(n=30)\end{array}$ & $\begin{array}{c}\text { Group D } \\
(n=30)\end{array}$ & ANOVA & p-value \\
\hline \multicolumn{7}{|c|}{ Duration of mechanical ventilation (hrs) } \\
\hline Mean $\pm \mathrm{SD}$ & $15.20 \pm 1.56$ & $14.60 \pm 1.94$ & $14.10 \pm 1.54$ & $14.10 \pm 2.01$ & \multirow[t]{2}{*}{1.603} & \multirow[t]{2}{*}{0.155} \\
\hline Range & $13-18$ & $12-18$ & $12-17$ & $12-18$ & & \\
\hline \multicolumn{7}{|c|}{ Length of stay in ICU(hrs) } \\
\hline Mean $\pm \mathrm{SD}$ & $26.60 \pm 4.82$ & $28.80 \pm 8.10$ & $30 \pm 8.19$ & $26.40 \pm 4.88$ & \multirow[t]{2}{*}{2.038} & \multirow[t]{2}{*}{0.112} \\
\hline Range & $24-36$ & $24-48$ & $24-48$ & $24-36$ & & \\
\hline \multicolumn{7}{|c|}{ Length of Stay in Hospital (days) } \\
\hline Mean $\pm \mathrm{SD}$ & $7.80 \pm 1.19$ & $7.80 \pm 1.42$ & $8 \pm 1.58$ & $7.70 \pm 1.21$ & \multirow[t]{2}{*}{0.258} & \multirow[t]{2}{*}{0.856} \\
\hline Range & $7-10$ & $7-11$ & $7-11$ & $7-10$ & & \\
\hline
\end{tabular}

F- One Way ANOVA; p-value >0.05 NS;

This table shows no statistically significant difference between groups postoperatively

Table (8): Correlation between bypass time, aortic cross clamping time, lowest MAP on bypass ,outcome evaluation of patient after surgery and development of kidney injury as indicated by elevation in serum creatinine and decrease in creatinine clearance, using Pearson Correlation Coefficient in group A.

\begin{tabular}{|l|c|c|c|c|}
\hline \multirow{2}{*}{ Group A } & \multicolumn{2}{c|}{$\begin{array}{c}\text { Serum creat } \\
\text { after 24hrs }\end{array}$} & \multicolumn{2}{c|}{$\begin{array}{c}\text { Creat clearance } \\
\text { after 24hrs }\end{array}$} \\
\cline { 2 - 5 } & $\mathrm{r}$ & $\mathrm{p}$-value & $\mathrm{r}$ & $\mathrm{p}$-value \\
\cline { 2 - 5 } & & & -0.751 & $<0.001^{* *}$ \\
\hline Serum creat after 24hrs & -0.751 & $<0.001^{* *}$ & & 0.185 \\
\hline Creat clearance after 24hrs & 0.102 & 0.593 & -0.249 & $<0.001^{* *}$ \\
\hline Bypass time (min) & 0.588 & $<0.001^{* *}$ & -0.584 & $<0.001^{* *}$ \\
\hline Time of aortic clamping (min) & -0.414 & $0.023^{*}$ & 0.693 & $<0.001^{* *}$ \\
\hline Lowest reading during bypass & 0.736 & $<0.001^{* *}$ & -0.892 & $<0.001^{* *}$ \\
\hline Duration of mechanical ventilation (hrs) & 0.775 & $<0.001^{* *}$ & -0.820 & $<0.001^{* *}$ \\
\hline Length of stay in ICU(hrs) & 0.743 & $<0.001^{* *}$ & -0.687 & $<$ \\
\hline Length of Stay in Hospital (days) & & & &
\end{tabular}

$r$-Pearson Correlation Coefficient

p-value $>0.05 \mathrm{NS}$; *p-value $<0.05 \mathrm{~S}$; **p-value $<0.001 \mathrm{HS}$

The table showed that in group (A) the more the time of bypass and time of aortic cross clamping and the lower MAP during bypass, the more the liability to develop kidney injury, as indicated by increased serum creatinine and decrease creatinine clearance.

Also the table showed the more the rise in serum creatinine, the more the duration of mechanical ventilation, more ICU stay and more hospital stay. 
Table (9): Correlation between bypass time, aortic cross clamping time, lowest MAP on bypass ,outcome evaluation of patient after surgery and development of kidney injury as indicated by elevation in serum creatinine and decrease in creatinine clearance, using Pearson Correlation Coefficient in group B.

\begin{tabular}{|l|c|c|c|c|}
\hline \multirow{2}{*}{ Group B } & \multicolumn{2}{c|}{$\begin{array}{c}\text { Serum creat } \\
\text { after 24hrs }\end{array}$} & \multicolumn{2}{c|}{$\begin{array}{c}\text { Creat clearance } \\
\text { after 24hrs }\end{array}$} \\
\cline { 2 - 5 } & $\mathrm{r}$ & $\mathrm{p}$-value & $\mathrm{r}$ & $\mathrm{p}$-value \\
\hline Serum creat after 24hrs & & & -0.859 & $<0.001^{* *}$ \\
\hline Creat clearance after 24hrs & -0.859 & $<0.001^{* *}$ & & \\
\hline Bypass time (min) & 0.602 & $<0.001^{* *}$ & -0.750 & $<0.001^{* *}$ \\
\hline Time of aortic clamping (min) & 0.359 & $0.049^{*}$ & -0.599 & $<0.001^{* *}$ \\
\hline Lowest reading during bypass & -0.507 & $0.004^{*}$ & 0.566 & $<0.001^{* *}$ \\
\hline Duration of mechanical ventilation (hrs) & 0.597 & $<0.001^{* *}$ & -0.788 & $<0.001^{* *}$ \\
\hline Length of stay in ICU(hrs) & -0.428 & $0.018^{*}$ & 0.219 & 0.244 \\
\hline Length of Stay in Hospital (days) & 0.816 & $<0.001^{* *}$ & -0.916 & $<0.001^{* *}$ \\
\hline
\end{tabular}

$r$-Pearson Correlation Coefficient

p-value $>0.05 \mathrm{NS} ;{ }^{*}$-value $<0.05 \mathrm{~S} ;{ }^{* *}$-value $<0.001 \mathrm{HS}$

The table showed that in group (B) the more the time of bypass and time of aortic cross clamping and the lower MAP during bypass, the more the liability to develop kidney injury, as indicated by increased serum creatinine and decrease creatinine clearance.

Also the table showed the more the rise in serum creatinine, the more the duration of mechanical ventilation, more ICU stay and more hospital stay.

Table (10): Correlation between bypass time, aortic cross clamping time, lowest MAP on bypass ,outcome evaluation of patient after surgery and development of kidney injury as indicated by elevation in serum creatinine and decrease in creatinine clearance, using Pearson Correlation Coefficient in group $\mathrm{C}$.

\begin{tabular}{|l|c|c|c|c|}
\hline \multirow{2}{*}{ Group C } & \multicolumn{2}{c|}{$\begin{array}{c}\text { Serum creat } \\
\text { after 24hrs }\end{array}$} & \multicolumn{2}{c|}{$\begin{array}{c}\text { Creat clearance } \\
\text { after 24hrs }\end{array}$} \\
\cline { 2 - 5 } & $\mathrm{r}$ & $\mathrm{p}$-value & $\mathrm{r}$ & $\mathrm{p}$-value \\
\hline Serum creat after 24hrs & & & -0.891 & $<0.001^{* *}$ \\
\hline Creat clearance after 24hrs & -0.891 & $<0.001^{* *}$ & & \\
\hline Bypass time (min) & 0.442 & $0.014^{*}$ & -0.576 & $<0.001^{* *}$ \\
\hline Time of aortic clamping (min) & 0.742 & $<0.001^{* *}$ & -0.784 & $<0.001^{* *}$ \\
\hline Lowest reading during bypass & -0.828 & $<0.001^{* *}$ & 0.778 & $<0.001^{* *}$ \\
\hline Duration of mechanical ventilation (hrs) & -0.163 & 0.390 & -0.095 & 0.618 \\
\hline Length of stay in ICU(hrs) & -0.156 & 0.411 & -0.200 & 0.289 \\
\hline Length of Stay in Hospital (days) & -0.110 & 0.564 & -0.169 & 0.373 \\
\hline
\end{tabular}

$r$-Pearson Correlation Coefficient

p-value $>0.05 \mathrm{NS} ;{ }^{*}$-value $<0.05 \mathrm{~S}$; **p-value $<0.001 \mathrm{HS}$

The table showed that in group (C) the more the time of bypass and time of aortic cross clamping and the lower MAP during bypass, the more the liability to develop kidney injury, as indicated by increased serum creatinine and decrease creatinine clearance.
Also the table showed no signifiacant correlation between the rise in serum creatinine and the duration of mechanical ventilation, ICU stay and hospital stay. 
Table (11): Correlation between bypass time, aortic cross clamping time, lowest MAP on bypass, outcome evaluation of patient after surgery and development of kidney injury as indicated by elevation in serum creatinine and decrease in creatinine clearance, using Pearson Correlation Coefficient in group D.

\begin{tabular}{|l|c|c|c|c|}
\hline \multirow{2}{*}{\multicolumn{1}{|c|}{ Group D }} & \multicolumn{2}{c|}{$\begin{array}{c}\text { Serum creat } \\
\text { after 24hrs }\end{array}$} & \multicolumn{2}{c|}{$\begin{array}{c}\text { Creat clearance } \\
\text { after 24hrs }\end{array}$} \\
\cline { 2 - 5 } & $\mathrm{r}$ & $\mathrm{p}$-value & $\mathrm{r}$ & $\mathrm{p}$-value \\
\hline Serum creat after 24hrs & & & -0.935 & $<0.001^{* *}$ \\
\hline Creat clearance after 24hrs & -0.935 & $<0.001^{* *}$ & & \\
\hline Bypass time (min) & 0.834 & $<0.001^{* *}$ & -0.795 & $<0.001^{* *}$ \\
\hline Time of aortic clamping (min) & 0.625 & $<0.001^{* *}$ & -0.509 & $0.004^{*}$ \\
\hline Lowest reading during bypass & -0.392 & $0.032^{*}$ & 0.273 & 0.144 \\
\hline Duration of mechanical ventilation (hrs) & 0.685 & $<0.001^{* *}$ & -0.504 & $0.004^{*}$ \\
\hline Length of stay in ICU(hrs) & 0.831 & $<0.001^{* *}$ & -0.732 & $<0.001^{* *}$ \\
\hline Length of Stay in Hospital (days) & 0.840 & $<0.001^{* *}$ & -0.751 & $<0.001^{* *}$ \\
\hline
\end{tabular}

$r$-Pearson Correlation Coefficient

p-value $>0.05 \mathrm{NS} ;{ }^{*}$-value $<0.05 \mathrm{~S} ;{ }^{* *}$ p-value $<0.001 \mathrm{HS}$

The table showed that in group (D) the more the time of bypass and time of aortic cross clamping and the lower MAP during bypass, the more the liability to develop kidney injury, as indicated by increased serum creatinine and decrease creatinine clearance.

Also the table showed the more the rise in serum creatinine, the more the duration of mechanical ventilation, more ICU stay and more hospital stay.

\section{DISCUSSION:}

The current study was designed to evaluate the possibility that NAC and bicarbonate could serve as a potential renal protector against reperfusion injury during cardiac bypass surgeries. It's a interventional, prospective, comparative, randomized, single blinded study placebo controlled study including four groups of patients. It was conducted in the Cardiothoracic Surgery Department of Ain Shams University hospitals, Cairo, Egypt. Study started June 2017 and ended December 2018.

$\mathrm{AKI}$ is not only a frequent complication in cardiac surgical patients, but has also been shown to be independently associated with morbidity and mortality. Unfortunately, little progress has been made within the last years in the development of strategies to reduce the incidence and improve the prognosis of this complication ${ }^{\mathbf{( 1 0 )}}$.

In the current study, serum creatinine and creatinine clearance were used for diagnosis of perioperative acute kidney injury (AKI).

The current study showed non significant correlation between usage of NAC and bicarbonate and renal protection after cardiac bypass surgeries.

Brown et al., showed that combination prophylaxis with NAC and $\mathrm{NaHCO} 3$ substantially reduce the occurrence of contrast induced AKI, but not dialysis dependent ${ }^{(\mathbf{1 1})}$.

Thayssen et al., ${ }^{(12)}$ showed that combined treatment with NAC and $\mathrm{NaHCO} 3$ didn't reduce the rate of CIN, but that combination may reduce the risk of renal dysfunction after 30 days.

The current study showed nonsignificant correlation between rise in serum creatinine, increased time of mechanical ventilation, increase length of stay in ICU and increase length of stay in hospital. 
The current study showed that usage of sodium bicarbonate led to metabolic alkalosis and hypernatremia.

Also the current study showed that the more the time of aortic clamping, time of $\mathrm{CPB}$ and the lower the MAP during CPB, the more the rise in serum creatinine after 24 hours.

Some studies were against this study and showed that NAC has a renoprotective role against oxidative stress during CPB. The role of NAC as an antioxidant in reducing the oxidative stress caused by the CPB had been investigated for a long time. In 2004, Sucu and his colleagues ${ }^{(13)}$ conducted a study to investigate the effect of NAC on preventing pump-induced oxidoinflammatory response during cardiopulmonary bypass, which was done on Fourty patients undergoing CABG who were randomly divided into a study group receiving NAC and control group, samples were collected for measurement of myeloperoxidase (MPO), malondialdehyde (MDA), interleukin-6, a1-acid glycoprotein (AAGP), and C-reactive protein (CRP) during surgery and postoperatively as oxidoinflamatory markers. The study showed that NAC pretreatment reduced the CPB induced oxido-inflammatory response, possibly by preventing the oxido-inflammatory cascade activation, as indicated by the marked attenuation of the markers.

Savluk et al., demonstrated that in patients with preexisting mild renal failure undergoing $\mathrm{CABG}$ surgery, intravenous NAC had a renoprotective effect, whereas continued low-dose dopamine (renal dose) had no protective effect. NAC caused a statistically significant increase in GFR, increased creatinine clearance and a decrease in creatinine ${ }^{(\mathbf{1 5})}$.

Fischer et al., showed that NAC reduced serum creatinine compared with the control group in their study. Moreover, Wijeysundera et al., ${ }^{(17)}$ found that there was preservation of postoperative GFR in patients with preexisting moderate renal dysfunction undergoing cardiac surgery and a significant reduction in mortality with NAC.

Sisillo et al., ${ }^{(19)}$ demonstrated a reduction in the incidence of the serum creatinine concentration with the usage of NAC in cardiac surgery. However, this reduction did not reach statistical significance.

Furthermore, Ayhan et al., ${ }^{(17)}$ found that two different regimens of $\mathrm{NAC}$ in $\mathrm{CABG}$ had some beneficial effects in the early the period of the surgery, but failed to demonstrate preventive effects in patients in the late phase.

Santana et al., showed that the incidence of kidney injury was reduced with NAC in CABG. They investigated two independent markers of kidney injury, namely cystatin $\mathrm{C}$ and neutrophil gelatinase associated lipocalin (NGAL). In the current study, the criteria used to characterize AKI were serum creatinine and creatinine clearance calculated by Cockcroft-Gault equation ${ }^{(\mathbf{1 8 )}}$.

It has been illustrated that NAC can reduce the risk of contrast nephropathy in humans, while the renoprotective effect of NAC on CPB remains controversial ${ }^{(19)}$.

Other studies agreed with the current study and showed that NAC usage wasn't significantly associated with reduction in serum creatinine and prevention of postoperative AKI.

Adabag et al., ${ }^{(20)}$ found that NAC was not significantly associated with decrease in serum creatinine levels, the incidence of AKI, hemodialysis requirements, operative mortality, intensive care, or length of hospital stay in patients undergoing cardiac surgery. These patients received oral NAC $600 \mathrm{mg}$ twice daily preoperatively, but the researchers administered NAC orally, and such administration may reduce its effectiveness. 
Tossios et al., (21) suggested that NAC application should begin before anesthesia induction to yield maximal benefit of its reactive oxygen species (ROS)-scavenging properties. Considering that the NAC is estimated to have a short half-life, at 2.2 hours, in the current study, $50 \mathrm{mg} / \mathrm{kg}$ of NAC was administered as the loading dose in $100 \mathrm{cc}$ of $0.9 \% \mathrm{NaCl}$ for 15 minutes; following this $20 \mathrm{mg} / \mathrm{kg} / \mathrm{h}$ of NAC was given as an infusion in $100 \mathrm{cc}$ of $0.9 \% \mathrm{NaCl}$ during the operation.

In the current study, NAC was started immediately after the induction of anesthesia, before the first surgical incision, intravenous dose of $150 \mathrm{mg} / \mathrm{kg}$ in $250 \mathrm{ml}$ of $5 \%$ glucose over $15 \mathrm{~min}$, followed by a continuous intravenous infusion of $50 \mathrm{mg} / \mathrm{kg}$ in $250 \mathrm{ml}$ of $5 \%$ glucose over $4 \mathrm{~h}$ and then $100 \mathrm{mg} / \mathrm{kg}$ in $250 \mathrm{ml}$ of $5 \%$ glucose over $20 \mathrm{~h}$.

Hyninen et al., ${ }^{(22)}$ demonstrated that NAC does not decrease the amount of kidney injury occurring in patients with normal preoperative renal function undergoing abdominal aortic surgery.

In addition, Sucu et al., ${ }^{(13)}$ found that intravenous NAC decreased the pumpinduced oxido-inflammatory response during CPB. In aortic surgery, it may result in kidney injury, and this may have different mechanisms, with the exception oxidoinflammatory damage ${ }^{(13)}$.

Haase et al., ${ }^{(8)}$ concluded that a high dose $(300 \mathrm{mg} / \mathrm{kg}$ intravenously) of NAC was no more effective than a placebo in attenuating CPB-related acute renal failure in high-risk cardiac surgery patients. Theoretically, high-dose NAC may have been excessive, and paradoxically, it may have diminished the level of radical oxygen species, thereby attenuating their potentially positive role in the regulation of intracellular signaling.

There has been no consensus on the identification of the most effective route and dose of NAC administration associated with significant renal protection in patients undergoing CABG. However, NAC is an inexpensive, relatively safe, well-tolerated, and widely used $\operatorname{drug}^{(14)}$.

Recently, Haase and coworkers have elegantly delineated a pathophysiological line of evidence that the severity of the renal insult induced by on-pump cardiac surgery may, at least in part, be related to the degree of hemoglobinuria: the histological features of CSA-AKI resemble the pigment nephropathy typically observed during rhabdomyolysis. Since alkalization of the urine is among the established measures to treat rhabdomyolysis, they used this concept successfully as a strategy for the prevention of CSA-AKI in a small pilot trial, the results of that prospective observational cohort study showed that perioperative treatment with bicarbonate does not reduce the incidence of CSA-AKI as measured by postoperative changes in creatinine, and the need for dialysis. Moreover, it is associated with clearly unwarranted effects like a decrease in arterial blood pressure (during the bolus application of bicarbonate an increased need for fluids and vasopressors, and an increased hospitalization time ${ }^{(8,16)}$.

The result of that study agreed with the current study that there was no statistically significant correlation between the usage of bicarbonate, decrease in serum creatinine and prevention of postoperative AKI.

Thus it is rather likely that the observed adverse effects in the intervention period were indeed related to the use of bicarbonate infusion, that is, alkalization, despite only achieving minimal changes in maximal plasma $\mathrm{pH}$. Data show that bicarbonate is frequently used in cardiac surgical patients to treat acidosis, especially during cardiopulmonary bypass. Despite this, few data are available on the short- and long-term hemodynamic effects of bicarbonate. Tripathi and coworkers observed a biphasic response after the infusion of bicarbonate $1 \mathrm{mmol} / \mathrm{Kg}$ BW during steady state conditions during 
CPB with an immediate venous pooling (leading to a decrease in the CPB reservoir volume), followed by a moderate increase in MAP. In contrast, observations in patients with end-stage renal disease show that higher dialysate bicarbonate concentrations lead to a decrease in arterial blood pressure during dialysis, an effect that may be explained by an increase in endothelial nitric oxide production $^{(\mathbf{1 8})}$.

Since the differences in maximal $\mathrm{pH}$ between the study groups were rather small ( $0.1 \mathrm{pH}$ difference) despite being statistically significant, one may assume that the lack of a nephroprotective effect of bicarbonate infusion may be related to the fact that no adequate alkalization was achieved ${ }^{(20)}$.

Haase and his colleagues tested a novel pathophysiological concept considering acute kidney injury being a potential sideropathy with oxidoinflammatory stress as a common unifying pathway causing cell injury aggravated by labile iron compounds (22).

They found that bicarbonate infusion achieved plasma and urinary alkalinization, but did not reduce kidney function deterioration indicated by serum creatinine concentration and urinary output. The current study demonstrated that there was no reduction of acute kidney injury or tubular protection after open heart surgery in patients who were administered sodium bicarbonate despite achieving adequate plasma and urinary alkalinization ${ }^{(26)}$.

Also causal association of systemically administered sodium bicarbonate and mortality appeared to be possible. Given that findings, they didn't recommend the routine prophylactic use of sodium bicarbonate infusion for that purpose ${ }^{(23,24)}$.

Haase et al, conducted a pilot doubleblinded, randomized control trial of 100 cardiac surgery patients. The patients underwent treatment to see if postoperative serum bicarbonate infusion can attenuate postoperative increases in serum creatinine. Their primary outcome was reaching a serum creatinine of $>25 \%$ above baseline within the first five postoperative days. They found a statistical significance using bicarbonate in patients with creatinine increases $>25 \%$ however there was no difference in patients with creatinine increases of either $>50 \%$ and $>100 \%$. There was no statistical significance found when acute kidney injury was defined by the AKIN criteria. No mortality benefit was seen in patients receiving postoperative serum bicarbonate infusion ${ }^{(21)}$.

Furthermore, other large RCT studies looking at n-acetylcysteine, fenoldopam and statins failed to show a clear benefit in postoperative renal protection ${ }^{(\mathbf{8}, 25)}$.

Mehta and colleagues showed that no difference was found between postoperative serum bicarbonate infusion and normal saline groups seen in the prospective pilot study ${ }^{(27,28)}$.

\section{Conclusion}

This study shows that perioperative intravenous administration of NAC with or without bicarbonate may not have a role in prevention of acute kidney injury in patients undergoing elective cardiac bypass surgeries as detected by serum creatinine and creatinine clearance.

\section{REFERENCES:}

1. Uchino S, Kellum JA, Bellomo R, Doig GS, Morimatsu H, Morgera S, Schetz M, Tan I, Bouman C, Macedo E, Gibney N, Tolwani A, Ronco C. Beginning, Ending Supportive Therapy for the Kidney I: Acute renal failure in critically ill patients: a multinational, multicenter study. JAMA 2005; 2 94: 813-818.

2. Karkouti K, Wijeysundera DN, Yau TM, Callum JL, Cheng DC, Crowther M, Dupuis JY, Fremes SE, Kent B, Laflamme C, Lamy A, Legare JF, Mazer CD, McCluskey SA, Rubens FD, Sawchuk C, Beattie WS. Acute 
kidney injury after cardiac surgery: focus on modifiable risk factors. Circulation 2009; 119: 495-502.

3. Englberger L, Suri RM, Connolly HM, Li Z, Abel MD, Greason KL, Dearani JA, Schaff HV. Increased risk of acute kidney injury in patients undergoing tricuspid valve surgery. Eur J Cardiothorac Surg 2013; 43: 993-999.

4. Rosner MD and Okusa MD. Acute kidney injury associated with cardiac surgery. Clin J Am Soc Nephrol 2006; 1: 19-32.

5. Zakeri R, Freemantle N, Barnett V, Lipkin GW, Bonser RS, Graham TR, Rooney SJ, Wilson IC, Cramb R, Keogh BE, Pagano D. Relation between mild renal dysfunction and outcomes after coronary artery bypass grafting. Circulation 2005; 112: I270-I275.

6. Mao H, Katz N, Ariyanon W, BlancaMartos L, Adýbelli Z, Giuliani A, Danesi $\mathrm{TH}$, et al.: Cardiac surgery-associated acute kidney injury. Cardiorenal Med 2013; 3:178-199.

7. Chertow GM, Lazarus JM, Christiansen CL, Cook EF, Hammermeister KE, Grover F, Daley J. Preoperative renal risk stratification. Circulation 1997; 95: 878 884.

8. Haase M, Haase-Fielitz A, Bagshaw SM, Reade MC, Morgera S, Seevenayagam S, et al. Phase II, randomized, controlled trial of high- dose $\mathrm{N}$-acetylcysteine in high-risk cardiac surgery patients. Crit Care Med. 2007; 35(5):1324-31.

9. Wang G, Bainbridge D, Martin J, Cheng D. $\mathrm{N}$-acetylcysteine in cardiac surgery: do the benefits outweigh the risks? A metaanalytic reappraisal. Journal of cardiothoracic and vascular anesthesia 2011; 25(2), 268-275.

10. Lassnigg A, Schmidlin D, Mouhieddine M, Bachmann LM, Druml W, Bauer P, Hiesmayr M. Impact of minimal increases in serum creatinine on outcome in patients after cardiothoracic surgery: Do we have to revise current definitions of acute renal failure? Crit Care Med 2008; 36:1129-1137.
11. Brown JR, Block CA, Malenka DJ, O'Connor GT, Schoolwerth AC, Thompson CA. Sodium bicarbonate plus Nacetylcysteine prophylaxis: a meta-analysis. JACC Cardiovasc Interv 2009; 2(11):111624.

12. Thayssen P, Lassen JF, Jensen SE, Hansen $\mathrm{KN}$, Hansen HS, Christiansen EH, et al.Prevention of contrast-induced nephropathy with $\mathrm{N}$-acetylcysteine or sodium bicarbonate in patients with STsegment-myocardial infarction: A prospective, randomized, open-labeled trial. Circulation: Cardiovascular Interventions 2014; 7(2): 216-224.

13. Sucu N, Cinel I, Unlu A, Aytacoglu B, Tamer L, Kocak Z, et al. N-acetylcysteine for preventing pump-induced oxidoinflammatory response during cardiopulmonary bypass. Surg Today. 2004; 34(3): 237-42.

14. Hollenberg NK, Adams DF, Mendell P, Abrams HL, Merrill JP. Renal vascular responses to dopamine: haemodynamic and angiographic observations in normal man. Clin Sci Mol Med. 1973; 45(6):733-42.

15. Savluk OF, Guzelmeric F, Yavuz Y, Cevirme D, Gurcu E, Ogus H, et al. Nacetylcysteine versus dopamine to prevent acute kidney injury after cardiac surgery in patients with preexisting moderate renal insufficiency. Brazilian Journal of Cardiovascular Surgery 2017; 32(1): 8-14.

16. Vanholder R, Sever M, Erek E: Rhabdomyolysis. J Am Soc Nephrol 2000; 11:1553-1561.

17. Wijeysundera DN, Beattie WS, Rao V, Granton JT, Chan CT. N-acetylcysteine for preventing acute kidney injury in cardiac surgery patients with pre- existing moderate renal insufficiency. Can J Anaesth. 2007; 54(11):872-81.

18. Schulz E and Munzel T: Intracellular pH: a fundamental modulator of vascular function. Circulation 2011; 124:1806-1807.

19. Sisillo E, Ceriani R, Bortone F, Juliano G, Salvi L, Veglia F, et al. N-acetylcysteine for prevention of acute renal failure in patients with chronic renal insufficiency undergoing 
cardiac surgery: a prospective, randomized, clinical trial. Crit Care Med. 2008; 36(1):81-6.

20. Ayhan B, Pamuk G, Kantar B, Kanbak M, Celebioglu B, Aypar U. Renal functional effects of using $\mathrm{N}$-acetylcysteine in cardiac surgery. Anesthesia J. 2012; 20: 159-67.

21. Haase M, Haase-Fielitz A, Bellomo R, Devarajan P, Story D, Matalanis G, Reade MC, Bagshaw SM, Seevanayagam N, Seevanayagam S, Doolan L, Buxton B, Dragun D. Sodium bicarbonate to prevent increases in serum creatinine after cardiac surgery: A pilot double-blind, randomized controlled trial. Crit Care Med 2009; 37:3947

22. Haase M, Bellomo R, Haase-Fielitz A. Novel biomarkers, oxidative stress, and the role of labile iron toxicity in cardiopulmonary bypass-associated acute kidney injury. J Am Coll Cardiol 55 2010; 2024-2033.

23. Kelly AM, Dwamena B, Cronin P, Bernstain SJ, Carlos RC. Meta-analysis: effectiveness of drugs for preventing contrast-induced neuropathy. Ann Intern Med. 2008; 148(4):284-94.
24. Thakar CV, Arrigain S, Worley S, Yared JP, Paganini EP. A clinical score to predict acute renal failure after cardiac surgery. $\mathrm{J}$ Am Soc Nephrol 2005; 16:162-168.

25. Adabag AS, Ishani, Bloomfield HE, Ngo AK, Wilt TJ. Efficacy of N-acetylcysteine in preventing renal injury after heart surgery: a systematic review of randomized trials. Eur Heart J. 2009; 30(15):1910-7.

26. Kumar A and Suneja M. Cardiopulmonary bypass-assoicated acute kidney injury. Anesthesiology; 2011, apr; 114(4):964-70.

27. Mehta RL, Kellum JA, Shah SV, et al: Acute Kidney injury network. acute Kidney injury network: report of an initiative to improve outcomes in acute kidney injury. Crit Care; 2007; 11(2): R31.

28. Tossios P, Bloch W, Huebner A, Raji MR, Dodos F, Klass O, et al. N-acetylcysteine prevents reactive oxygen species-mediated myocardial stress in patients undergoing cardiac surgery: result of a randomized, double-blind, placebo-controlled clinical trial. J Thorac Cardiovasc Surg. 2003; 126(5):1513-20. 